\title{
Efficiency of Quality Assurance Implementation on Selective Study Program Using Data Envelopment Analysis
}

\author{
Rorim Panday \\ Bhayangkara Jaya University,Management, Jakarta,Indonesia \\ indripan@gmail.com
}

\section{Doi:10.5901/mjss.2015.v6n5s5p196}

\section{Abstract}

\begin{abstract}
To meet the customer's satisfaction and the desire for a product, quality assurance needs to be done, not least higher education. Education is once of the production activities of services. Smallest part operation of education at the college is a study program (Prodi), where in this section, educate students to certain discipline. To ensure graduates of study programs become qualified, then Indonesia ministry of education, research and technology (previously was Kemdikbud), made instruments for quality assurance called Internal Quality Evaluation (EMI), with the aim that every Prodi produce quality students. EMI is essentially measure the performance in implementing quality assurance at prodi, used eight national education standards, which then developed become 10 national education standards. When first time implement EMI in 2011, applied to selected study program. Use data of internal quality evaluation of the study programs, this study objective is to determine the level of efficiency of the implementation of quality assurance at selected study program by using Data Envelopment Analysis (DEA). Of the 36 study programs that computed the relative efficiency, 16 study programs have been efficient in the implementation of EMI while 20 study programs have not been efficient in carrying EMI.
\end{abstract}

Keywords: Internal Quality Evaluation, Data Envelopment Analysis, efficient, efficiency

\section{Introduction}

In 2010, the Ministry of Education and Culture, represented by the general directorate of higher education, run a quality assurance program for university, that universities in Indonesia to be quality university. There are already several programs that lead to such things as standards for external quality assurance (SPME= Sistem Penjaminan Mutu Eksternal) and internal quality assurance standards (SPMI=Sistem Penjaminan Mutu Internal). As instruments of SPME then formed the National Accreditation Board of Higher Education (BAN-PT), whereas for the implementation of SPMI submitted to the respective universities. Each higher education develops instruments used as the implementation of internal quality assurance. As a result, the data obtained from each university vary greatly in terms of format and content. Based on these events, the quality assurance of Kemdikbud made a standard instrument for SPMI, so that the data obtained from such instruments could be used by parties of Kemdikbud to make policy in terms of management of higher education which can help universities develop into a quality of higher education. The instrument is called the Internal Quality Evaluation (EMI). With the EMI's, to (1) help universities and government set development programs towards fulfilling the SNP (National Education Standards), and (2) avoid a gap between the results of the internal with the external evaluation. EMI created by: (1) a variety of standards applicable internationally (AUN, Webometric) to help governments and universities to develop quality education and be able to compete in the regional and international arena, (2) the diversity of potential and resources of universities in Indonesia, as well as (3) examples of good practice that exist in Indonesia. (Direktur Jenderal Pendidikan Tinggi, 2006). Results of the EMI shown the performance of the implementation of quality assurance. Of the execution of EMI, has not carried out an analysis of the efficiency level of quality assurance implementation. For that research is done, by using a sample selective Prodi that has done its internal quality evaluation using instruments EMI. The objective of this study was to determine the level of relative efficiency between selective Prodi in the implementation of EMI. By knowing the efficiency level, then it could be an advanced guidance for universities to be able to improve the efficiency of the implementation of EMI Prodi.

\section{Literature Review}

In the system of national education of Indonesia, emphasized need for quality assurance in education, being a college that quality higher education is done in a sustainable manner, resulting in continuous improvement (Sistem Pendidikan 
Nasional, 2003). For that Kemdikbud (ministry of education and culture) prepared quality assurance instrument called Internal Quality Evaluation (EMI=Evaluasi Mutu Internal). There are three types of EMI generated are EMI-institution, EMI-Prodi and EMI for Workforce Education Institutions (LPTK). EMI institutions instrument consists of 11 of education standards; EMI instrument for Prodi and LPTKs consists of 10 educational standards (Kementerian Pendidikan dan Kebudayaan, 2012) such as: standard of content of education, standard of teaching learning process, standard of assessment, standard of management, standard of faculty and staff, standard of facilities and infrastructure, standard of competency of graduates, standard of financing, standard of research, and standard of service to the community. Results of EMI in the form of a score of ten standards, according to which an description of the implementation of the EMI performance. These data will be used to compute the relative efficiency among the selective study program use Data Envelopment Analysis.

Data envelopment analysis (DEA) is a non parametric. DEA method assumes that not all entities are efficient. DEA is able to analyze more than one input and / or output using linear programming model that generates a single efficiency value for each study. DEA developed by (Charnes, Cooper, and Rhodes, 1978), known as CCR models. In this model, a level of efficiency is calculated by the ratio of output to input by weighting each. To determine the weight carried out by the linear program.

There are a lot of scientific literature that explains the sense of DEA. According to (Ramanathan, 2003), DEA is a linear programming based technique for measuring the efficiency of the organizational unit called Decision Making Units (DMU). DEA is a mathematical programming technique used to evaluate the relative efficiency of a set of decisionmaking unit (DMU) in managing resources (input) so that it becomes the result (output) where relationships form the function of input to output is not known. DEA as a method that can be used to measure the comparative efficiency of homogenous operating units such as schools, hospitals, and so on. According to (Cooper, Seiford, and Joe Zhu, 2000), DEA uses mathematical technical program that can handle many variables and constraints, and does not restrict the input and output that would have been due to technical used can be overcome. DMU is of organizations or entities to be measured relative efficiency to other entities that homogeneous group. Homogeneous means that the input and output of the DMU is evaluated to be the same / similar. DMU can be either commercial or public entities, such as commercial banks or the government, private or public schools, hospitals, and so on. DEA had been developed next by (Banker, Charnes, and Cooper, 1984), so the model is called a model of BCC. BCC models using the assumption of variable returns to scale (VRS), while using the CCR models assuming constant returns to scale (CRS). CRS assumption requires that a DMU is able to increase or decrease the input and output linearly without an increase or decrease in the value of efficiency. While the assumption of VRS does not require changes in the input and output of a DMU takes place in a linear manner, so that allowed the increase (increasing returns to scale / IRS) and decrease (decreasing returns to scale / DRS) value of efficiency. CRS assumption is suitable when all DMU working at optimum capacity (economies of scale). There are several types of DEA models that may be used depending on the conditions of the problems faced. There are 4 models DEA which can be used in research, namely CRS Input, CRS Output, VRS input and VRS output.

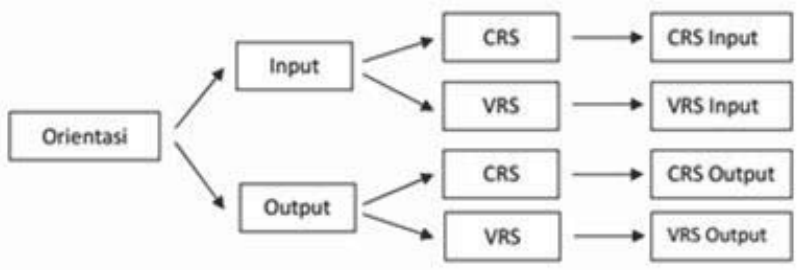

Figure 1. Classification of DEA basic model

CRS and VRS shows the assumptions used, while input and output show the orientation of research. Orientation input is used if, emphasis on reducing inputs to increase efficiency. Input orientation assumes that management has more control on input rather than output, or in other words, management is able to add and subtract inputs with ease. Instead, the orientation of the output is used if the emphasis on increasing output with input provided to increase the value of efficiency. This means that the management has more control of the output from the input. According to (Yazar A. Oscan, 2008), the measurement of efficiency can be performed by various methods, namely ratio analysis, least-squares regression (LSR), total factor productivity (TFP), stochastic frontier analysis (SFA), and data envelopment analysis (DEA). College efficiency calculations largely apply Data Envelopment Analysis (DEA) (Ahn et al., 1988). Several studies relating 
to the use of DEA in education issues carried out by (Handaru Jati, April,2015) about efficiency rating of LPTK university in Indonesia, (Martin Flégl \& Kristýna Vltavská, 2013) about efficiency at Faculties of Economics in the Czech Public Higher Education Institutions: Two Different Approaches, (Zara Daghbashyan, 2011) research about The Economic Efficiency of Swedish Higher Education Institutions, (Emilio Martin, 2003) research about Application of the Data Envelopment Analysis Methodology in the Performance Assessment of the Zaragoza University Departments, and (Altamirano-Corro et al,2012) research about measuring the institutional efficiency using data envelopment analysis and analytic hierarchy process: The case of a Mexican University. All of them used secondary data, different variables depend on reserach goals, use CCR method and limited to the technical efficiency. All of those research can be said as experimental research.

\section{Methodology}

This research is quantitative research as case studies by selective 36 studies program as DMU (Decision Makning Unit) at 5 universities in Java. Those selective sample is taken from the EMI supervision between year of 2011-2013 done by self of researcher, used EMI instrument which has been made by Kemdikbud. Data collection process has been explained in (Panday, 2014). So, the type of data is primary data, in form of score value in scale 1 to 100 which is in contrast to past studies that have been discussed in the review of the literature. And also different in variables used. Data used from EMI is the score value of 10 education standard assessment for each study program. Education standard was defined as variables. Score each education standard represent the performance of EMI implementation at Prodi. Using those score value, will be computed relative efficiency among the selective study program, use Data Envelopment Analysis method, as referred to(Ahn et al., 1988). Before computing the efficiency, it is needed to define which of the 10 education standards (Kementerian Pendidikan dan Kebudayaan, 2012), including as input and as output, are shown in Table 1.

Table 1. Input and ouput definition variables

\begin{tabular}{clc}
\hline Code & Standar dalam instrumen EMI & Designed to \\
\hline SDT1 & Standard of content & Input \\
SDT2 & Standard of Process & Input \\
SDT3 & Standard of graduate competency & Output \\
SDT4 & Standar d of Lecturer and staff education & Input \\
SDT5 & Standard of facilities and infrastructure & Input \\
SDT6 & Standard of management & Input \\
SDT7 & Standard of financing & Input \\
SDT8 & Standard of evaluation & Input \\
SDT9 & Standard of research & Output \\
SDT10 & Standard of society dedication & Output \\
\hline
\end{tabular}

Computation of relative efficiency using software OSDEA (Open Software Data Envelopment Analysis). This study using the CCR models assuming constant returns to scale (CRS) and also limited to the technical efficiency as explained in (Yazar A. Oscan, 2008).

\section{Discussion, Findings and Interpretations}

The result of efficiency computation shown at table- 2 .

Table 2. The result of efficiency Computation

\begin{tabular}{|c|l|c|c|}
\hline No & DMU Name & Objective Value & Efficient \\
\hline 1 & Teknik Kimia Unsera & 0,819330897 & \\
\hline 2 & Akuntansi Unsera & 1 & Yes \\
\hline 3 & Manajemen Unsera & 1 & Yes \\
\hline 4 & Fisip Adm Negara Unsera & 1 & \\
\hline 5 & Fisip Komunikasi Unsera & 0,726099844 & \\
\hline 6 & Teknik Industri Unsera & 0,921977181 & \\
\hline
\end{tabular}




\begin{tabular}{|c|l|c|c|}
\hline 7 & Teknik Sipil Unsera & 1 & Yes \\
\hline 8 & FTI Sistem informasi Unsera & 0,921977181 & \\
\hline 9 & FTI sistem kopmputer Unsera & 0,921977181 & \\
\hline 10 & FTITeknik Informatika Unsera & 0,992616298 & \\
\hline 11 & Pendidikan Biologi UMMI & 0,928002665 & \\
\hline 12 & PJKR UMMI & 0,873516685 & \\
\hline 13 & BPSI UMMI & 0,839522678 & \\
\hline 14 & IPA UST & 0,941925591 & \\
\hline 15 & Matematika_UST & 0,912729754 & \\
\hline 16 & Senirupa UST & 1 & Yes \\
\hline 17 & BPSI UST & 0,917415843 & \\
\hline 18 & PGSD UST & 0,926440615 & \\
\hline 19 & PKK UST & 0,96020502 & \\
\hline 20 & PTM UST & 0,9570064 & \\
\hline 21 & Fisika UST & 0,993730106 & Yes \\
\hline 22 & Bahasa Inggris-UST & 1 & Yes \\
\hline 23 & Agribisnis UST & 1 & Yes \\
\hline 24 & Agroteknologi UST & 1 & Yes \\
\hline 25 & Akuntansi UST & 1 & Yes \\
\hline 26 & Manajemen UST & 1 & Yes \\
\hline 27 & Psikologi UST & 1 & Yes \\
\hline 28 & Sipil UST non LPTK & 1 & Yes \\
\hline 29 & Bahasa Unsur & 0,913990381 & \\
\hline 30 & Matematika Unsur & 1 & Yes \\
\hline 31 & PJKR Unsur & 0,874547456348983 & \\
\hline 32 & PPKN Unsur & & \\
\hline 33 & Ekonomi Fkip Unswagati & 1 & \\
\hline 34 & Matematika Fkip unswagati & 1 & \\
\hline 35 & Bahasa Indonesia unswagati & 1 & \\
\hline 36 & Bahasa Inggris Unswagati & 1 & \\
\hline & & 1 & \\
\hline & & \\
\hline
\end{tabular}

Based on the result of computation, there are 16 study programs have efficient in implementation of internal quality assurance, indicate by the efficiency value as 1, the rest, 20 study programs have not efficient in implementation of internal quality assurance, indicate by the efficiency value less than one. Inefficiency of 20 study program, because there are still have positif slack of input production factor (see table-3). It is mean, using of production input factor have not efficient. Range of the slack between 0,02 to 37,30 .

Table 3. Slack of each study program

\begin{tabular}{|l|c|c|c|c|c|}
\hline DMU Name & STD1 & SDT2 & SDT3 & ST4 & SDT5 \\
\hline Teknik Kimia Unsera & 12,42 & 1,36 & 0 & 37,30 & 0 \\
\hline Akuntansi Unsera & 0 & 0 & 0 & 0 & 0 \\
\hline Manajemen Unsera & 0 & 0 & 0 & 0 & 0 \\
\hline Fisip Adm Negara Unsera & 14,28 & 0 & 14,29 & 28,57 & 14,28 \\
\hline Fisip Komunikasi Unsera & 0 & 2,63 & 0 & 2,24 & 0 \\
\hline Teknik Industri Unsera & 0 & 0 & 0 & 4,03 & 3,49 \\
\hline Teknik Sipil Unsera & 0 & 0 & 0 & 0 & 0 \\
\hline FTI Sistem informasi Unsera & 0 & 0 & 0 & 4,03 & 3,49 \\
\hline FTI sistem kopmputer Unsera & 0 & 0 & 0 & 4,03 & 3,49 \\
\hline FTITeknik Informatika Unsera & 0 & 4,96 & 0 & 0 & 14,71 \\
\hline Pendidikan Biologi UMMI & 0 & 0 & 0 & 3,59 & 0 \\
\hline PJKR UMMI & 0 & 0 & 0 & 0 & 8,10 \\
\hline BPSI UMMI & 3,03 & 3,60 & 0 & 0 & 12,60 \\
\hline IPA UST & 4,21 & 0,72 & 5,65 & 7,45 & 5,60 \\
\hline Matematika_UST & 1,63 & 0 & 0 & 9,88 & 0,80 \\
\hline Senirupa UST & 0 & 0 & 0 & 0 & 0 \\
\hline BPSI UST & 8,48 & 0 & 0 & 18,44 & 3,87 \\
\hline PGSD UST & 25,44 & 0 & 14,29 & 5,35 & 14,85 \\
\hline
\end{tabular}




\begin{tabular}{|c|c|c|c|c|c|}
\hline PKK UST & 0 & 0 & 0 & 5,48 & 0 \\
\hline PTM UST & 0 & 0,02 & 0 & 2,37 & 0,66 \\
\hline Fisika UST & 2,77 & 0 & 0 & 18,59 & 20,24 \\
\hline Bahasa Inggris-UST & 0 & 0 & 0 & 0 & 0 \\
\hline Agribisnis UST & 0 & 0 & 0 & 0 & 0 \\
\hline Agroteknologi UST & 0 & 0 & 0 & 0 & 0 \\
\hline Akuntansi UST & 0 & 0 & 0 & 0 & 0 \\
\hline Manajemen UST & 0 & 0 & 0 & 0 & 0 \\
\hline Psikologi UST & 0 & 0 & 0 & 0 & 0 \\
\hline Sipil UST & 0 & 0 & 0 & 0 & 0 \\
\hline Bahasa Unsur & 0 & 0 & 0 & 0 & 0 \\
\hline Matematika Unsur & 0 & 2,07 & 0 & 7,80 & 0 \\
\hline PJKR Unsur & 2,86 & 7,51 & 0 & 0 & 1,33 \\
\hline DMU Name & SDT6 & SDT7 & SDT8 & SDT9 & SDT10 \\
\hline PPKN Unsur & 0 & 0 & 0 & 0 & 0 \\
\hline Ekonomi Fkip Unswagati & 0 & 0 & 0 & 0 & 0 \\
\hline Matematika Fkip unswagati & 0 & 0 & 0 & 0 & 2,79 \\
\hline Bahasa Indonesia unswagati & 0 & 0 & 0 & 0 & 0 \\
\hline Bahasa Inggris Unswagati & 0 & 8,14 & 0 & 0 & 3,83 \\
\hline Teknik Kimia Unsera & 3,38 & 0 & 2,18 & 0 & 0 \\
\hline Akuntansi Unsera & 0 & 0 & 0 & 0 & 0 \\
\hline Manajemen Unsera & 0 & 0 & 0 & 0 & 0 \\
\hline Fisip Adm Negara Unsera & 14,28 & 14,28 & 28,57 & 14,29 & 0 \\
\hline Fisip Komunikasi Unsera & 3,83 & 0 & 0,58 & 0 & 0 \\
\hline Teknik Industri Unsera & 4,78 & 27,07 & 0 & 2,86 & 0 \\
\hline Teknik Sipil Unsera & 0 & 0 & 0 & 0 & 0 \\
\hline FTI Sistem informasi Unsera & 4,78 & 0,73 & 0 & 2,86 & 0 \\
\hline FTI sistem kopmputer Unsera & 4,78 & 0,73 & 0 & 2,86 & 0 \\
\hline FTITeknik Informatika Unsera & 10,16 & 15,66 & 9,52 & 0,68 & 0 \\
\hline Pendidikan Biologi UMMI & 3,43 & 0,56 & 12,43 & 0 & 25,51 \\
\hline PJKR UMMI & 7,73 & 11,42 & 4,49 & 0 & 2,84 \\
\hline BPSI UMMI & 4,79 & 0 & 12,35 & 0 & 27,53 \\
\hline IPA UST & 0 & 0 & 5,94 & 0 & 0 \\
\hline Matematika UST & 0 & 8,36 & 2,77 & 0 & 0 \\
\hline Senirupa UST & 0 & 0 & 0 & 0 & 0 \\
\hline BPSI UST & 0,60 & 0 & 11,52 & 2,46 & 0 \\
\hline PGSD UST & 13,52 & 18,83 & 6,24 & 0 & 5,36 \\
\hline PKK UST & 9,32 & 0,89 & 0,78 & 0 & 0,28 \\
\hline PTM UST & 0 & 2,50 & 7,72 & 0,60 & 0 \\
\hline Fisika UST & 0 & 0 & 8,98 & 4,66 & 0 \\
\hline Bahasa Inggris-UST & 0 & 0 & 0 & 0 & 0 \\
\hline Agribisnis UST & 0 & 0 & 0 & 0 & 0 \\
\hline Agroteknologi UST & 0 & 0 & 0 & 0 & 0 \\
\hline Akuntansi UST & 0 & 0 & 0 & 0 & 0 \\
\hline Manajemen UST & 0 & 0 & 0 & 0 & 0 \\
\hline Psikologi UST & 0 & 0 & 0 & 0 & 0 \\
\hline Sipil UST & 0 & 0 & 0 & 0 & 0 \\
\hline Bahasa Unsur & 0 & 0 & 0 & 0 & 0 \\
\hline Matematika Unsur & 0,85 & 0 & 0,85 & 0 & 11,46 \\
\hline PJKR Unsur & 4,32 & 0 & 2,25 & 11,58 & 2,57 \\
\hline PPKN Unsur & 0 & 0 & 0 & 0 & 0 \\
\hline Ekonomi Fkip Unswagati & 0 & 0 & 0 & 0 & 0 \\
\hline Matematika Fkip unswagati & 3,64 & 4,80 & 7,41 & 0 & 6,56 \\
\hline Bahasa Indonesia unswagati & 0 & 0 & 0 & 0 & 0 \\
\hline Bahasa Inggris Unswagati & 0,37 & 0 & 6,96 & 0 & 9,57 \\
\hline
\end{tabular}


If orientation to input is used, by reducing inputs will increase efficiency. In input orientation assumes that management has more control on input rather than output, or in other words, management is able to add and subtract inputs with ease. Instead, if the orientation of the output is used, the emphasis on increasing output with input provided, will increase the value of efficiency. This means that the management has more control of the output from the input.

Because of in this study used CCR method, so, based on the analysis, it is important for study program that have not efficient, to improve their efficiency can be done by decrease the input to increase efficiency. As other result of this study, data of rating score can be used in DEA. In this research, ten education standars constitute the homogeneous variables in measurement of performance of implementation. So that, by using EMI for larger data for all prodi in Indonesia, its possible used to determine the relative level of efficiency all prodi.

\section{Conclussions}

This study shown how the relative efficiency level of implementation of quality assurance at selective study program. Data of Evaluation of Internal Quality (EMI) as the performance of quality assurance, also represent as measurement of implementation of Quality assurance. Using those data, at the selective of study program at Jawa, of 36 study programs from 5 universities, 16 study programs have efficient, while 20 of study programs have not efficient in implementing of quality assurance. The inefficiency of the study program, because at 20 study programs still have positive slack, or using of production input factor have not efficient.

\section{References}

Ahn, T., Charnes, A. \& Cooper, W.W. (1988). Some statistical and DEA evaluations of relative efficiencies of public and private institutions of higher learning. Socio-Economic Planning Sciences, Vol. 22, No. 6, pp. 259-269

Altamirano-Corro et al.(2012). Measuring the institutional efficiency using data envelopment analysis and analytic hierarchy process: The case of a Mexican University. African Journal of Business Management Vol. 6(50), pp. 11923-11930, 19 December, 2012 .Available online at http://www.academicjournals.org/AJBM. DOI: 10.5897/AJBM10.770. ISSN 1993-8233 @2012 Academic Journals

Banker, R.D., Charnes, A., and Cooper, W.W. (1984). Models for the estimation of technical and scale inefficiencies in Data Envelopment Analysis. Management Science 30, 1078-1092.

Charnes, A.W., Cooper, W.W. \& Rhodes, E. (1978). Measuring Efficiency of Decision Making Units. European Journal of Operational Research, Vol. 2, pp. 429-444.

Cooper William W., Lawrence M. Seiford and Joe Zhu.(2000). Data Envelopment Analysis History, Models and Interpretations .Red Mc Combs School of Business, Universityof Texas at Austin, Austin, TX 78712 USA. Retrieved from :http://www.google.co.id lurl?sa=t\&rct=j\&q=\&esrc=s\&source=web\&cd=3\&cad=rja\&uact=8\&ved=0CCkQFjAC\&url=http\%3A\%2F\%2Fwww.researchgate.net \%2Fprofile\%2FLawrence_Seiford\%2Fpublication\%2F226038831_Data_Envelopment_Analysis_History_Models_and_Interpretati ons\%2Flinks\%2F0912f5087477782603000000.pdf\&ei=F2A0VcCōJtGiugSG04CIDA\&usg=AFQjCNG3mX̄gcfLnlccxdhJWhWUNM nE1bTA\&sig2=ns7xytNspnDPPTgcGfmEaQ\&bvm=bv.91071109,d.c2E

Direktorat Jenderal Pendidikan Tinggi Departemen Pendidikan Nasional.(2006). Panduan Pelaksanaan Sistem Penjaminan Mutu Perguruan Tinggi (SPM-PT)Bidang Akademik.

Emilio Martin .(2003). An Application of the Data Envelopment Analysis Methodology in the Performance Assessment of the Zaragoza University Departments. Retrieved from: http://www.dteconz.unizar.es/DT2003-06.pdf

Handaru Jati.(2015, April). Penilaian efisiensi Universitas LPTK di Indonesia Dengan Menggunakan Data Envelopment Analysis. Program Studi Pendidikan Teknik Informatika, Universitas Negeri Yogyakarta. Retrieved from: http://staff.uny.ac.id/sites/ default/files/penelitian/Handaru\%20Jati,\%20ST.,M.M,\%20M.T,\%20Ph.D/Penilaian\%20Efisiensi\%20Universitas\%20LPTK\%20di\% 20Indonesia\%20dengan\%20Data\%20Envelopment\%20Analysis\%20.pdf

Kementerian Pendidikan dan Kebudayaan.(2012). Evaluasi Mutu Internal Perguruan Tinggi Indonesia. Badan Pengembangan Sumber Daya Manusia Pendidikan dan Kebudayaan dan Penjaminan Mutu Pendidikan Pusat Penjaminan Mutu Pendidikan, Bidang Pendidikan Menengah dan Pendidikan Tinggi

Martin Flégl \& Kristýna Vltavská. (2013). Efficiency at Faculties of Economicsin the Czech Public Higher Education Institutions: Two Different Approaches. Department of Systems Engineering, Faculty of Economics and Management, Czech University of Life Sciences Prague, Prague, Czech Republic. doi:10.5539/ies.v6n10p1 URL: http://dx.doi.org/10.5539/ies.v6n10p1. International Education Studies; Vol. 6, No. 10; 2013. ISSN 1913-9020 E-ISSN 1913-9039 .Published by Canadian Centerof Science and Education.

Ozcan, Yasar A. (2008). Health Care Benchmarking and Performance Evaluation. Springer, New York

Panday, Rorim (2014). Implementasi Penjaminan Mutu Dalam Menghadapi Globalisasi, Analisis dan Implikasi: Studi kasus, makalah disampaikan pada Seminar Nasional Universitas Maranatha 23-24 may 2014, di Bandung

Ramanathan.(2003).An Introduction to Data Envelopment Analysis. Sage Publications Inc, New Delhi

Sistem Pendidikan Nasional.(2003).Undang-undang Republik Indonesia Nomor 20 Tahun 2003 tentang Sistem Pendidikan Nasional 
Zara Daghbashyan.(2011).The Economic Efficiency of Swedish Higher Education Institutions. Division of Economics CESIS, KTH, CESIS Electronic Working Paper Series.Paper No. 245.The Royal Institute of technology Centre of Excellence for Science and Innovation Studies (CESIS). http:///www.cesis.se 